\title{
INTRODUCING SETOS ON STAGE: ON THE EARLY PERFORMANCES OF SETO SINGING CULTURE
}

\author{
Andreas Kalkun
}

\begin{abstract}
The article introduces the choirs who were active in Räpina Parish, south-eastern Estonia, in the late nineteenth century, and toured Estonian towns with their concerts in which they impersonated Setos. The performances of the "Setos" were entertaining or commercial, and humorous dialogues and plays in the Seto language ${ }^{1}$ or its imitation were as important as the music at these performances. The "Setos" and the "Seto language" were presented to the audiences as a curiosity next to other entertaining attractions. The performances of Seto culture by men from Räpina Parish followed the traditional models of representing exotic cultures at the time. On the one hand, the peculiar construction of Seto culture by the "Setos" from Räpina represented a revival of the imagined past and, on the other hand, it was a demonstration of ethnic culture foreshadowing the modern folklore movement in the commercial space between folk tradition and elite culture. The early performances of the Seto singing culture represent the searches coinciding with the period of national awakening in Estonia and the curious detours from own national heritage to explore the close Others, the Seto people, though in a very peculiar manner.
\end{abstract}

Keywords: commercial demonstration of Seto culture, impersonating Setos, Räpina Parish, Seto folklore, singing and drama societies

In September 2008, the Republic of Estonia submitted an application for the Seto polyphonic singing culture to be included in the UNESCO Representative List of Intangible Cultural Heritage of Humanity. On 30 September 2009, the committee convened in Abu Dhabi, United Arab Emirates, and decided to inscribe 76 cultural phenomena, including the Seto leelo, or the Seto polyphonic singing culture, in the Representative List of Intangible Cultural Heritage of Humanity. The Seto singing culture became the third item from the Republic of Estonia to be included in this list. ${ }^{2}$

Towards the end of the nineteenth century, when knowledge of Seto culture reached the wider literate circles in Estonia through the mediation of folklorists and linguists, ${ }^{3}$ the first performances of Seto culture and choir singing were organised on stage outside the Seto region. Curiously, though, instead of Setos, 
the performers at these first staged performances of Seto music and culture outside their home region were Estonians impersonating Setos. According to several late nineteenth-century reports, some choirs from Räpina Parish in Võru County (i.e. the areas neighbouring the Seto region) performed in different parts of Estonia as Setos, wearing ethnic Seto clothes, performing music advertised as Seto folk music or humorous dialogues in the Seto language. Such cultural appropriation or fakelore-related demonstrations of Seto culture were organised outside the Seto region since their target audience were people who had not seen or heard it before and, for obvious reasons, there was no need for these in the Seto region where folklore lived its "first life". The performances were organised by Estonians who were able to see value in the uniqueness and exoticism of this "archaic" oral culture and quite adequately perceived which part of Seto culture would be appealing for and well-received by the audiences of other cultural backgrounds. The Estonians performing Seto culture probably knew well what needed to be done to adapt the lived tradition for the stage. This type of performance was usually commercial in nature as it was organised for profit or for raising funds for charity. The men from Räpina who performed as Setos also took part in the first Estonian song festivals (see Põldmäe 1969, 1976), which, regardless of the entertaining and commercial elements, were viewed as a serious patriotic activity.

After the incorporation of Seto areas in the Republic of Estonia in 1919, the polyphonic Seto choirs with their attractive ethnic clothing and "exotic" voices ${ }^{4}$ were often chosen to represent the indigenous or traditional Estonian culture. From time to time there have been some pesky voices asking who the Seto women represent when they perform on stages in Paris or Helsinki. Is it Estonian or Seto culture? Why should Seto culture represent Estonian culture (see, e.g., Salve 2000: 55; Piho 2003) ${ }^{5}$ It is, however, even more difficult to answer the question about who the men from Räpina represented for the late nineteenth-century audiences as they travelled around the country performing these "Seto" songs and culture. Did they represent the "prehistoric Estonian culture" that was depicted through Setos, "the backward kin brothers" of Estonians, or simply some exotic and attractive Others, who were deployed for a comical effect for the Estonian audiences?

In the following I will introduce popular demonstrations of Seto culture and singing by non-Setos outside the Seto region in the late nineteenth and early twentieth centuries. My focus is on the displays of Seto singing culture organised for entertaining or commercial purposes. Information about the performances and concerts is traced in newspapers, memoirs, and contemporary documents. The article aims to identify the repertoire and performance style of the concert 
performances, to introduce the discussions prompted by these performances, and the reception of "Setos" by the Estonian audiences. I will also explore the possible contexts and causes of this phenomenon.

\section{SETOS VS ESTONIANS FROM RÄPINA PARISH: THEIR IMAGE AND DIFFERENCES IN THE SINGING TRADITIONS AT THE END OF THE NINETEENTH CENTURY}

In the nineteenth century, the prevalent theory was that Setos were Estonians who had once emigrated from their homeland to escape slavery and had been Russianised by the Russian Orthodox Church (Kreutzwald 1953: 105, 108; see also Lillak 2014; Hagu 1978: 618; Mägiste 1957: 170-173; Tampere 1956: 275-277). Researchers of language and folklore viewed Setos as "the perfect primal Estonians" with their preserved archaic quality, which would be useful in the studies of Estonian history and folklore (see Jääts 1998). In light of the theories about peoples' development at the time, it was believed that Setos were 100-200 years behind Estonians. Among folklorists, for example, Rudolf Põldmäe (1938: 3) explicitly claimed that Setos were a century behind Estonians in their "development", while folklorist Jakob Hurt (1989: 42) believed that the difference was at least a few hundred years. Hindrik Prants, a man of letters, folklore collector and history enthusiast, argued that Setos truthfully demonstrated the situation in which "our ancestors lived centuries ago" and that their language and customs were "largely" the kind known from thousands of years ago (Prants 2016 [1910]: 28). The "archaic" Seto folklore was believed to be the key to many questions related to Estonian folklore and history.

Although linguistically closely related, ${ }^{6}$ Setos and their Lutheran neighbours in the early twentieth century were highly different in terms of educational or socio-economic circumstances. While at the end of the nineteenth century the Seto region was covered with a sparse Russian-language school network and the literacy rate among Setos was $0.6-0.9$ percent (Lõuna 2003: 18), in Võru County literacy was relatively common. In the early twentieth century, the literacy rate increased also in the Seto region, but the difference with the Võru region was still significant. In 1926 the literacy rate among the population of Võru County aged 15 and above was 90 percent, whereas in the Seto region the literacy rate was 44 percent (Võrumaa 1926: 89). ${ }^{7}$ The Livonian part of the Russian Empire with its Lutheran religion, network of schools, and a different economic situation contrasted with the Seto region in the Pskov area. When discussing Setos, intellectuals from Livonia preferred to underline the remarkable difference 
between the two neighbouring "kinsfolk". In his ethnographic description of Setos (published in Russian and German), Jakob Hurt, for example, found it necessary to emphasise that, unlike Setos, their kinsfolk and adjacent neighbours, Estonians in Livonia, are "twentieth-century cultural people, through and through, with their vices and virtues" (Hurt 1903: 189). Throughout Jakob Hurt's writings, however, Setos are characterised as "primitive", although the term had a neutral connotation in the academic literature of the period, and it is used to describe both the nature of Setos and their religion. At the beginning of the twentieth century, the contrast between the close neighbours and kinsfolk was so stark that Jakob Hurt and Hindrik Prants had to explain in their popularising articles that Setos indeed were "our" close kindred people (see Hurt 1989: 147; Prants 2016 [1910]: 29).

When in the late nineteenth century folklore collectors argued that the archaic folklore was disappearing in Livonia, the Seto region was viewed as the "last stronghold" where old folk songs could still be found in abundance. Jakob Hurt argued that the songs of Estonians in Livonia were long forgotten whereas the "archaic" Seto folklore was still practised and as topical as daily bread.

These archaic songs and tales - long forgotten in Estonia and Livonia, set aside to a storage chamber like some useless and despised junk and brought out with considerable effort only by overly eager and tireless researchers - are still held in esteem in the land of Setos and are used in everyday life like daily bread is used to nurture one's body. The memories of Setos and their ancestors cannot be separated. In these memories, Setos search and find elevation to their joys and ending to their sorrows - the teachings of the forefathers are their Bible and reflect in their lives. So it is no wonder that scholars travel to the Seto region as for them this land is a golden well for getting to know the olden times and prehistoric things. (Hurt 1904: V)

To use Lauri Honko's classical definition, in the late nineteenth and early twentieth centuries, the singing tradition in the Seto region indeed lived its "first life" in the singing community. According to Honko, the first life of folklore is when folklore is not particularly noticeable, acknowledged or valued because it is an organic part of everything that is happening (see Honko 1990). The tradition did not have a name or clearly delineated subcategories and it was not emphasised for ideological purposes. Folklore lived its life and served its function in the cultural system and in rituals. Even though some rituals entailed a custom to pay to the performer of the tradition (e.g., paid wedding singers, donations to the lamenting bride, several songs for collecting money 
at weddings), in most cases singing or dancing was not related to commercial transactions. The singing tradition was generally known but there were, no doubt, some who were more specialised in the tradition - in Seto culture, for example, wedding singers and the so-called lauluimä' or "mothers of song". With the arrival of folklore collectors and the intensifying recording of folk songs in the early twentieth century, changes slowly began to take place within the Seto singing culture. Things that had never happened before - such as women from a patriarchal Seto village singing to non-Seto men for money, performing songs to non-Seto audiences outside the ritual practices for economic or other reasons, etc. - started to take place (see Kalkun 2015: 157ff.; Kuutma 2006: 149).

In the immediate vicinity of the Seto region, Räpina Parish, the singing tradition had acquired completely different characteristics. The older folk song had been left to be transmitted by the marginal groups of a lower social status (elderly women, indigent and poorly educated peasants), whereas the choirs and brass bands representing newer and often borrowed tradition had become the more prestigious and prominent part of the music life in the parish. The (initially male) choirs of Räpina successfully participated in the first country-wide song festivals in Tartu (in 1869 and 1879) and in Tallinn (in 1880), and performed at regional singing events in Põlva (in 1855 and 1857) (see Karheiding 1925; Ritsing 1978, 1984: 136). ${ }^{8}$ The choir was mainly composed of more educated members of the community (pastors, church sextons, and school teachers), but there were also less educated but ambitious peasants among the singers. The earliest choir active in Räpina Parish was the choir of schoolmasters of the Räpina urban settlement (led by a schoolteacher and church sexton Thomas Undritz), which operated in 1850-1897. Some time later (in 1879-1898), the male (at times also mixed) choir of Tooste (Toosikatsi/Toosekatsi) village started its activity under the lead of choral conductor Jakob Puksov, a schoolteacher by profession, but at times also that of Herman Julius Schmalz. For a shorter period, towards the end of the nineteenth century, a male choir led by Viido Kiudosk and church sexton Daniel Punnisson was active in Mehikoorma urban settlement (Karheiding 1925; Ritsing 1978, 1984).

In the late nineteenth century, folklore collectors and educated locals alike regarded the earlier singing tradition of Räpina Parish as something foreign and different. Owing to its unique features (the "archaic" nature, long texts with monotonic and repetitive musical structure) it was perceived as something similar to the Seto singing tradition. Regardless of that, when Jakob Hurt added folk songs collected from Räpina Parish in his monumental anthology of Seto folk songs, ${ }^{9}$ the locals found it problematic. "The people of Räpina and Vastseliina are not too keen on having them and their folk songs grouped together 
with Seto songs," wrote a reviewer of the work, very likely representing many others who had been offended by being grouped together with the "backward" Setos (Reiman 1904: 291).

\section{ON THE EARLY DEMONSTRATIONS OF SETO CULTURE}

The earliest instances of showcasing Seto customs, ethnic clothing, and songs outside the Seto region (by Setos themselves) have disappeared seemingly without a trace. The first precisely documented traces of the performances of real Seto choirs, or other demonstrations of Seto culture outside the Seto region by Setos themselves date back to the beginning of the twentieth century, and it seems that Setos had not been brought on stage before that. The first reports about the new ways of organising Seto choirs and singing outside the traditional environment can be found in the correspondence between Karl Usstav, an innovative priest from Tailova in Seto region, who fought for Setos to have school education, and folklorist Oskar Kallas. In 1911, the priest of Tailova informed Oskar Kallas about the visits of the Hungarian ethnologist Aldar Ban to study Seto ethnography, and the Finnish linguist Heikki Ojansuu to collect folk songs in the Seto region. Usstav mentions among other things: "I'm working hard with a Seto choir and plan to come to perform in Tartu the next summer" (EKLA, f 186, m 76:8, 1 1/1). ${ }^{10}$ The planned concert in Tartu most likely took place, because it is known that on May 16, 1912, some twenty or so Setos in festive clothes were brought to Tartu, where a celebratory event was held in Vanemuine Theatre to raise funds for the Estonian National Museum. The Setos who participated in the event were photographed for the museum's postcards by a Tartu photographer Woldemar Thomson (photographs No. 27-45 in the album of the Estonian National Museum; see Pildialbum 2008: 59ff.). The ensemble depicted on the postcards is captioned as "A choir of singers from Pechory", featuring not only portraits but also what appear to be scenes of demonstrations of wedding rituals, such as "The godfather is invited to the wedding", "The bride bows to godfather", "Fun at the wedding - nailing the horseshoe", "The bridal couple says farewell", "The bridal couple is taken to the sauna" (Fig. 1), etc.

Still, performances of groups who called themselves "Seto choirs" took place in Estonian cities and towns also in the nineteenth century. The first performances of Seto culture outside their home region had been held in the late nineteenth century, already before Jakob Hurt announced his famous call for 


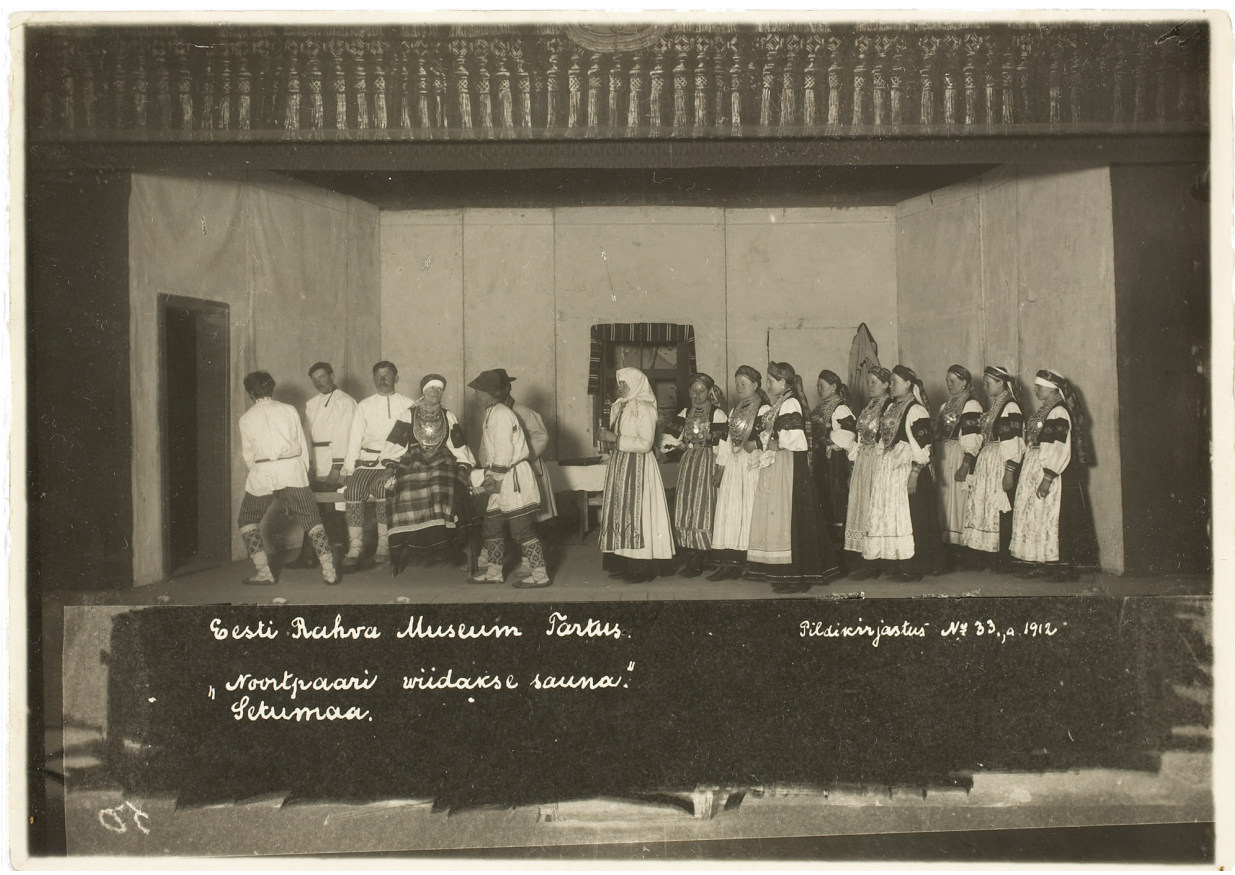

Figure 1. Setos in Vanemuine Theatre: "The bridal couple is taken to the sauna". Photograph by Woldemar Thomson, 1912 (Estonian National Museum, ERM Fk 235:22).

collecting folklore (in 1888) and years before the first volume of Setukeste laulud ('Seto folk songs', Hurt 1904) was published. Thus, it is safe to agree that it happened before the understanding of vanavara ('old treasures', as folklore was called at the time) and of Seto folklore that something particularly archaic and valuable had been mediated to the general public via newspapers. The performances of choirs appearing as Setos followed the traditional model of representing exotic peoples, their ethnic clothing and customs on stage. Showcasing Setos could thus be viewed as a representation of the alienating and exoticising of a minority group. Such performances, no doubt, shared semblance with the colonialist showcasing and ethnographic performances of "primitive tribes", and thus inherently entailed the less tactful representation exploiting the Seto culture. 


\section{DISPLAYS OF EXOTIC CULTURES IN THE NINETEENTH- CENTURY ESTONIAN TOWNS}

Musicologists and historians have studied the concerts and staged plays organised in different parts of Estonia in the nineteenth century (see, e.g., Lippus 2008; Rohtla 2005, 2006). Next to the high culture of the elite, the research has also covered, for example, musical performances held at home (Lippus 2012), whereas circus performances, entertainment offered at local fairs, and displays of exotic peoples and cultures have not been studied thus far. Having briefly browsed the nineteenth-century Estonian newspapers, I have found evidence that the displays of exotic cultures were a popular form of entertainment at the time. In the following I bring as an example of commercial demonstrating of exotic cultures an overview of media representations of the performances of black-skinned ensembles. ${ }^{11}$ This was clearly not a phenomenon specific only to Estonia; instead, what happened on the territory of Estonia was a modest reflection of what happened in the major centres of the tsarist empire. For example, it is obvious that the performances of so-called "Negroes" in Tallinn, Tartu, and Viljandi were only single stops on longer tours in the cities of the Russian Empire. Occasionally, such demonstrations of exotic cultures or circus performances held in St. Petersburg made news also in the sensational foreign reports section of Estonian-language newspapers.

A choir of Negroes is giving concerts in the hall of the credit society, and they attract large crowds. They say that the Negroes' singing is so in tune and beautifully precise that people have rarely heard such nice singing here before. The national songs that the Negroes perform among other repertoire are reportedly quite peculiar. (Postimees 1895a: 2)

Nevertheless, it is likely that not many of such groups demonstrating exotic peoples for commercial purposes performed in Estonia before the second part of the nineteenth century, as at least the promotional advertisements sometimes emphasised the fact that it was, for example, the "Negroes" very first visit.

On the 10th day of this month and perhaps also later, four Negroes from America will be singing at a concert in the [Tartu] townspeople's club. This is indeed the first time that Negroes are giving a concert in this town. We have heard Negroes singing in Germany; it was very beautiful. Maybe it will be the same here. Black men have often very beautiful voices. And perhaps it is worth listening to them here as well. They would not come and give a concert in a land so far away if they were not fine singers. (Eesti Postimees 1882: 4) 
The performances of the "Negro" culture and music were organised either in the open air (e.g., behind the Coastal Gate or the Harju Gate of the city wall of Tallinn) or in the rented rooms of various German societies (e.g., the German artisans' society or the townspeople's club in Tartu, or the farmers' society in Viljandi). At the open air performances also exotic animals were shown, and the advertisements characterise the foreigners as "funny", "peculiar", "wondrous", and "uneasy-making".

This year, the people of Tallinn have a chance to see something rather peculiar behind the Coastal Gate. A group of black men, about 20 of them, full-bred Negroes from Ashanti and its neighbourhood, will be performing their humour and antics, which are rather wondrous and uneasy for our people to see. They have also brought rather many tropical animals with them - elephants, camels, etc. (Postimees 1889: 3)

The reviews of such concerts sometimes gave overviews of the cultures the performers represented, which were obviously typically prejudiced and disparaging. For example, a review of a concert held in Tallinn emphasised the demonstrated "heathen" practices, the performers' lack of education, and even cannibalism. ${ }^{12}$ "They are Negroes, very ill-educated people, among whom human sacrifice and other heathen atrocities are still practised" (Tallinna Sõber 1889: 3). Like elsewhere in Europe, such performances were combined with freak shows and circus acts; at the Tallinn event in 1889, for example, also "dwarfs" performed in a play next to the "Negroes", and there were strongmen and other performers providing entertainment for people. The representatives of exotic cultures were probably also eroticised for the stage - for example, an advertisement of the performance of "Negroes" in Tartu emphasised the scanty clothing worn by the latter:

The boys from dark hell, the men of the black country will be performing for a couple of days starting from Tuesday, 10th of October, at 3, 5, and 9 p.m. in the rooms kindly provided by the German artisans' society. Negroes from the Pepper Coast in the land of Africa! Under the lead of Nanna Kru King's son, "Prince Kwente Nimsa”, you'll see the peculiar dances, spear throwing, sword and knife fights, fist fights, etc. of their faraway homeland, accompanied by the scantily clad dark pagan boys' singing and praying to their gods. Tickets 50 and 35 kopecks. Children's tickets 25 and 15 kopecks. Director Albert Urbach. (Postimees 1895b: 4)

The significant number and differences of ensembles presenting exotic cultures are further confirmed in the discussions over the groups' authenticity in the 
reviews of the performances. After a concert held in 1884 in Viljandi, a reviewer doubts whether the performers who advertised themselves as "Negroes" were in fact what they claimed to be. As the performers spoke fluent Russian, the reviewer believes they were Russian Gypsies instead, and not at all as exotic, and so the reviewer feels ripped off (Sakala 1884: 2). The advertisement published before the performance of "the Negroes of Nanna Kru" assures spectators of the performers' exotic descent: "These are true African people and their dances and ethnic games are from the land of Africa, not impersonation" (Postimees 1895c: 3).

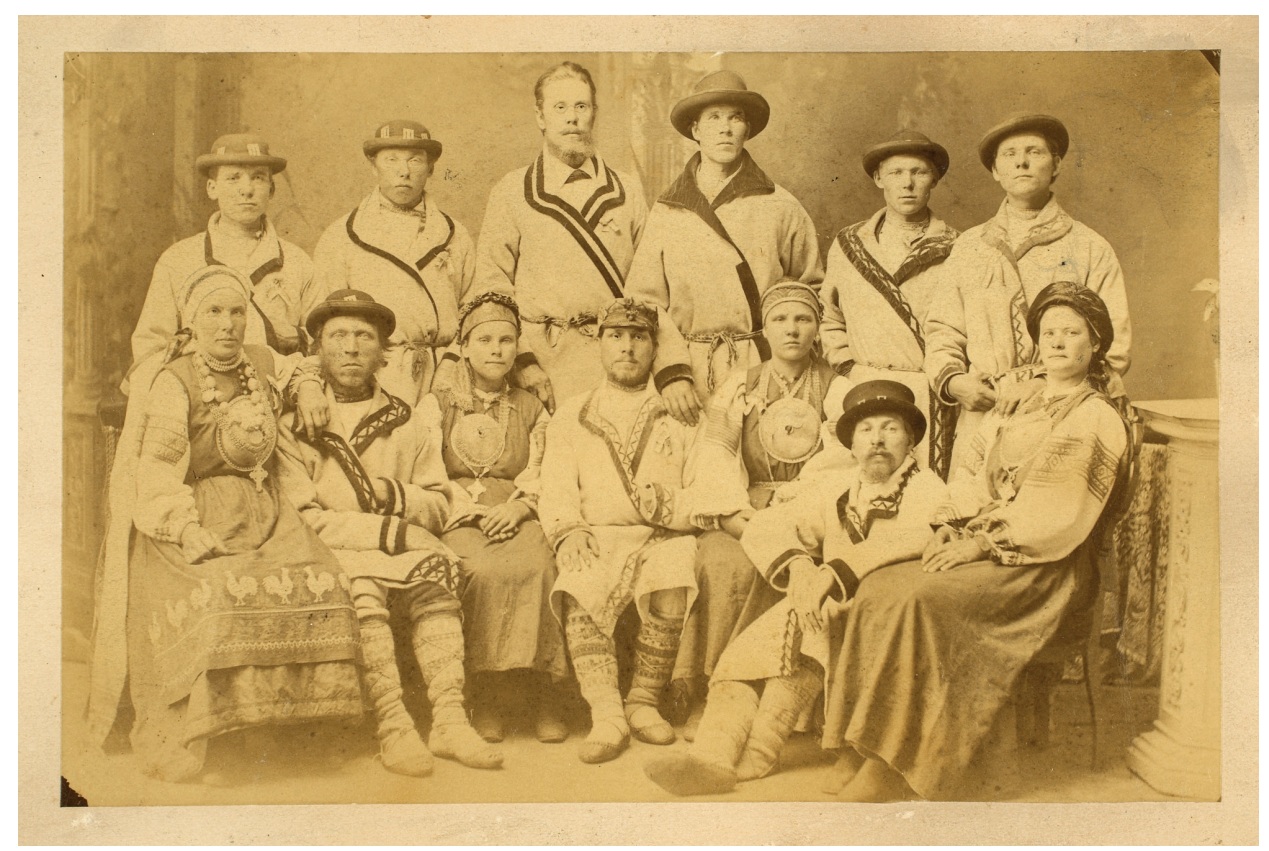

Figure 2. The choir of Tooste singing and drama society. Photograph by Reinhold Sachker, 1894 (Estonian National Museum, ERM Fk 1235:37). 


\section{MEN FROM RÄPINA PARISH IMPERSONATING SETOS}

As unexpected as it may be, evidently some Estonian choirs that were active in Räpina Parish performed as Setos on a regular basis in the late nineteenth and early twentieth centuries. At such performances, the choirs wore Seto clothing, sang songs that were called Seto songs, danced folk dances and acted out humorous dialogues, sometimes even plays, in the Seto language. The activities of the choir of Tooste (Toosikatsi) singing and drama society are the best documented ones (the choir was active in 1879-1898; see Ritsing 1978; Karheiding 1925: 71). The choir started out as a double quartet and had only male singers. Later on, occasionally also female singers sung with the choir (Fig. 2).

The existing chronicle of the choir ${ }^{13}$ as well as people's memoirs about the choir's activities indicate that at one point the more important performances of the choir involved acting as Setos and performing Seto culture. In the following I will take a closer look at the choir's activities focusing on an 1886 performance of the choir in Tartu. This was, by all appearances, a very important performance in the history of the choir, as it is later discussed both in personal recollections and in overviews of the choir's activities. A close reading of the information available about the performance could possibly give some idea about the creative aspirations and the performance repertoire of the "Seto choir", but also the objectives and ideology behind such performances. An early account on the history of choir singing in Räpina Parish by Karheiding reads as follows:

The Tooste choir sometimes performed under the name of the "Seto choir" and they were often dressed in Seto clothing at these performances. The more important events were:

1) A couple of folk celebrations in Tartu. During one performance they danced a Seto circle game, during another a Seto play was staged at the Vanemuine Theatre on two nights in succession, followed by dancing. The young men in Tartu were very willing to dance with the "Seto" girls. Mr. Listakind, one of the "Setos", could not help himself and danced so vehemently that when he left the theatre building and stepped out on the street, he felt that his feet were cold: it turned out that his dancing had worn out his traditional leather shoes and foot wraps. At a festivity in Tartu, Jakob Puksov gave a speech in the Seto dialect over a "bad dream", in which he ridiculed Grenzstein, as he, like many other young people at the time, sided with Jakobson. ${ }^{14}$ They were paid for the performances (one time 15 roubles by the Vanemuine Theatre, once 10 roubles by Johanson from Luke manor, etc.) and once received the third prize. 
2) A song festival.

3) A singing and folk festival in Tallinn, performing a play in Seto clothes.

(Karheiding 1925: 71)

This fragment of a recollection gives some idea of the geographical scope of the choir's performances and the nature of the programmes of the Estonians performing as a Seto choir. They performed to large crowds in larger towns; some events were highly prestigious ones (song festivals) and the performances were chargeable. Dancing with the audience and funny plays were of equal importance with singing. The abovementioned "speech" by Jakob Puksov (a longterm choir leader) was probably more like a stand-up comedy or monodrama, joking about topical politics (see Aabrams 2016). Advertisements of the "Setos" performances in the newspapers of the period also give some idea of their context and style. The performance of the Tooste choir at the folk festivity of the Vanemuine Society in Tartu, on 17 August 1886, was highlighted as a unique event and promoted as Setos' very first visit to Tartu. ${ }^{15}$ The advertisement also mentions the ethnic clothing, the Seto language, and emphasises that the songs and plays to be performed would be funny.

Setos in Tartu for the first time ever - wearing national clothes, singing many funny songs and telling humorous tales in the Seto language! (Postimees 1886a: 4)

The programme of the folk festivity was structured in the way that the performances of single and joint choirs and orchestras were followed by various other attractions, such as a "silent play", moving pictures, farces by actors of the Vanemuine Theatre, a circus show with trained horses and an Indian elephant, etc. According to the advertisement, Setos took the floor after the entertainment, right before the flower auction and carousel ride. A review of the concert in the next issue of the newspaper Postimees ('The Courier') praised the great celebration and announced that the Seto choir was awarded the third prize among male choirs in the choir singing contest of 22 choirs.

Now it is time to focus on the singing contest in which altogether 22 choirs participated. The choirs here were given sufficient time to show how proficient they had become in the sweet art of singing. Among the mixed choirs, the 1st prize was awarded to the Kõrveküla mixed choir, the 2nd prize to the Kardla mixed choir, and the 3rd prize to the Kärevere mixed choir; of the male choirs, the 1st prize was given to the Kavilda male choir, the 2nd prize to the Suur-Konguta male choir, and the 3rd prize to the Setos' male choir. (Postimees 1886b: 1) 
So, evidently, the Seto choir was not only part of the exotic entertainment besides an Indian elephant and trained horses but also participated in the serious choir singing contest. The programme of the joint choirs' concert featured, among other things, choir songs by Estonian composers in German Liedertafel style. ${ }^{16}$ Performing these songs certainly required special preparation and experience in singing European choral music. The chronicle of the choir also reveals that at this Tartu performance, the Tooste men who performed as the "Seto choir" enjoyed great popularity both when singing the European choir music and in the later performance of folk songs.

\section{TRADITIONAL SETO CLOTHES AS EXOTIC SHOW COSTUMES}

Even though in most cases the Tooste choir performed as a male choir (they also competed in the category of male choirs), it appears that in the more entertaining part of the aforementioned Tartu event they performed also as a mixed choir. Namely, the reviewer of the event expressed approval about using ethnic clothing at the event and mentioned that the young women in the choir wore very beautiful and unique ethnic costumes. ${ }^{17}$ Both the concert advertisement and the review highlight the exotic clothing of the Seto choir. The traditional clothing thus played an important role in the transformation process. The chronicle of the Tooste singing and drama society choir does not reveal the reasons why they chose to perform as Setos, but a chronicle entry from 1886 mentions that the choir performed "under the name of the Seto choir" at the event of the

Figure 3. "Seto choir". Photograph by Heinrich Tiidermann (Estonian History Museum, F 11684:136).

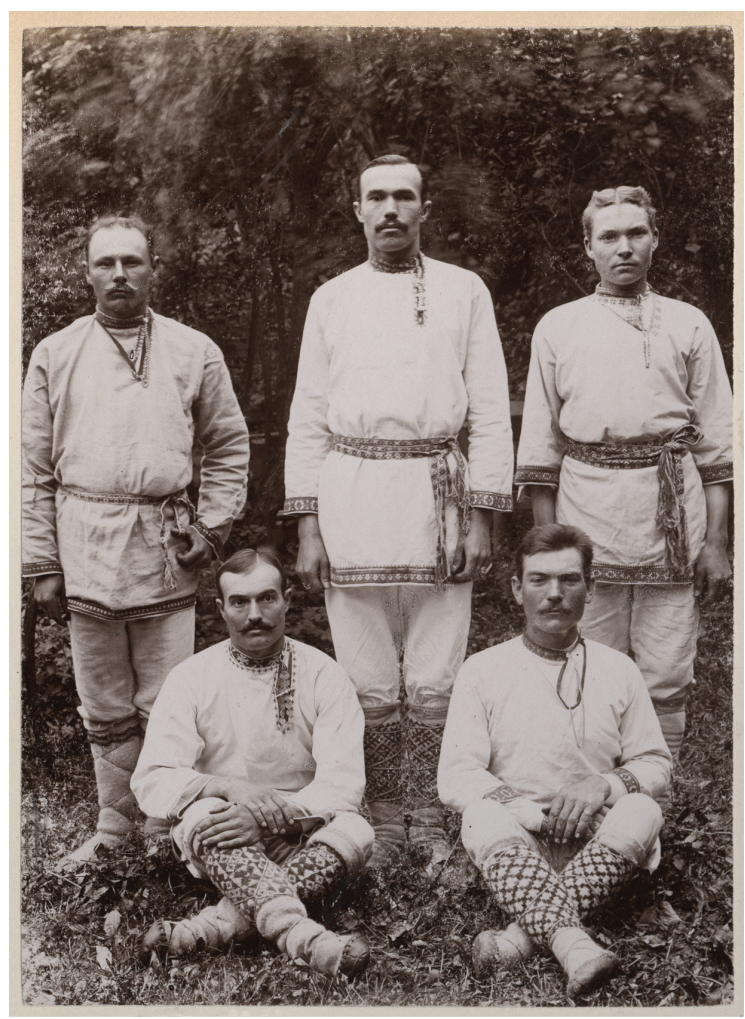




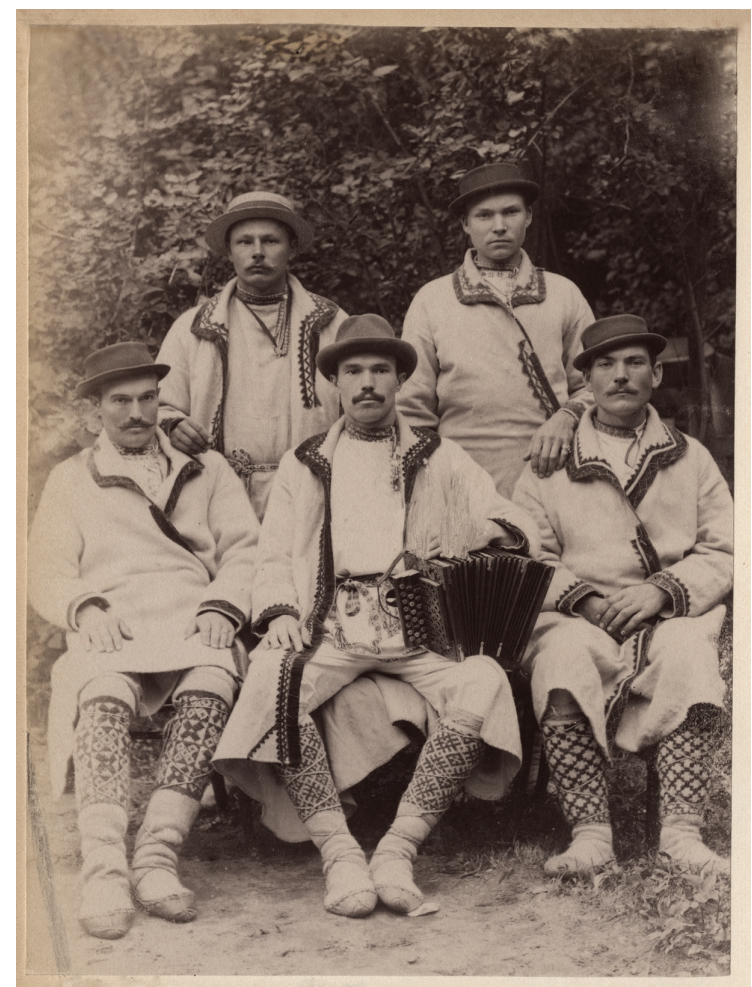

Figure 4. "Seto choir". Photograph by Heinrich Tiidermann (Estonian History Museum, F 11684:153).

Figure 5. "Seto choir". Photograph by Heinrich Tiidermann (Estonian History Museum, F 11684:155).

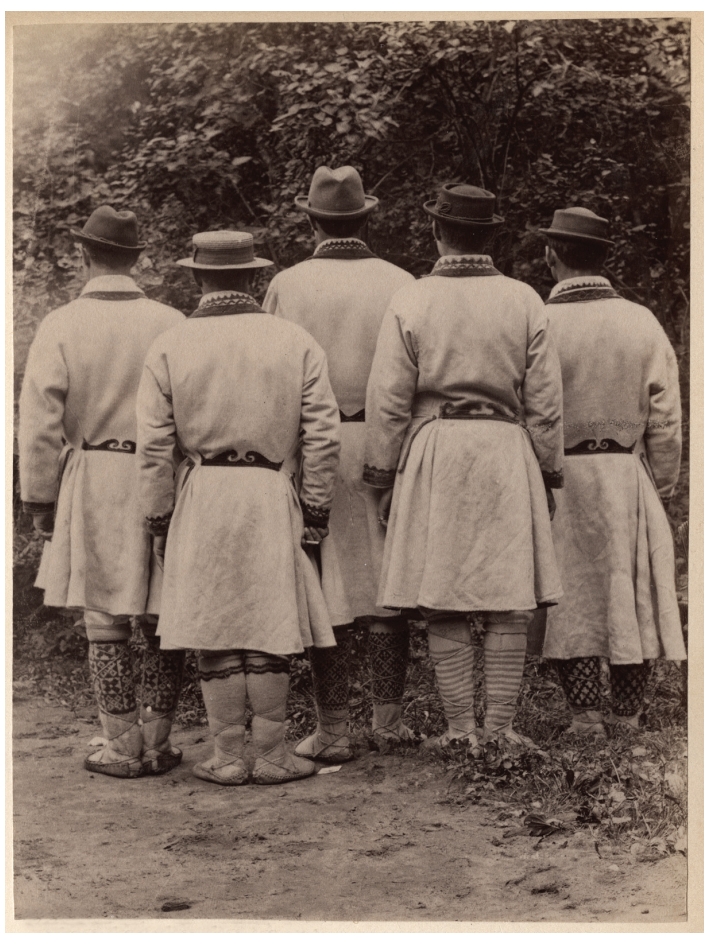


Vanemuine Society and at Luke manor, and sung Seto songs while wearing Seto clothing. ${ }^{18}$

The choir's chronicle reveals that the clothing had been purchased from Seto people by A. Zernask, who was suspected of having profited from the deal. Zernask was later evicted from the choir, but the chronicle does not say whether it was because of this suspicious clothing purchase or some other misdeed.

This A. Zernask has spent much money on Seto clothes and the Setos are saying that this is not right. This is why Jakob Song and Joosep Puksov were delegated to get the money from Zernask and make him accountable before the society about how much money he has spent. Whatever they can get back from Zernask, they can keep half of it and the society gets the other half. They will have to deal with it within a fortnight. (EKLA, f $169, \mathrm{~m} \mathrm{152:1,} 1$ 16p)

Already the procurement of these Seto clothes raised the issue of their authenticity because Setos had criticised the clothing worn by the choir from Räpina Parish, claiming these to be "incorrect" ones. Photographs depicting the Tooste choir indeed show that the Estonian women did not know how to correctly tie the headdress of married Seto women and, also, their costumes were a peculiar mix of everyday and festive Seto clothing (see Figs. 2-5). The clothes of the choir seem to aspire to certain unity, because all the men in the photographs are dressed in long woollen Seto coats. These Estonian men, dressed uniformly in Seto long coats, have been believed to be so "Seto-esque" that the photo depicting the fake Setos from Tooste has been later repeatedly captioned as "Seto men". Interestingly, they have appeared most recently on a postcard issued by the Estonian National Museum. Thus the respectable gentlemen in white coats and patterned knee-socks have appeared to be more authentic and "truer" than the real Seto men of the period, as the latter used to wear much more versatile clothing.

Evidence of the fact that the choirs of Räpina Parish impersonated Setos already before the Tooste choir's performances is an 1880 letter by Viido Kiudosk, a choir conductor from Mehikoorma, to the organising committee of the third nationwide song festival. Namely, singers from Mehikoorma expressed their wish to organise solo concerts where they would perform clothed as Setos. The choir leader wrote of their plan to "put on a concert of the old songs of the Estonian people, dressed in old Estonian ethnic clothes, or, as we would say - a Seto concert and Seto clothes". Kiudosk referred to this performance as "a little joke" that would enrich the festivities"

Recollections of the contemporaries also reveal that the traditional Seto clothing was used by the Räpina choirs only as an attractive performance costume 
to underline the ethnic, archaic or "authentic" quality of the repertoire. For example, some recall a performance in Tallinn which had almost failed for the reason that the choir had been commissioned to perform in ethnic clothes but they had not brought these along. Apparently, so little was known about Setos that their traditional clothing could be replaced with any other exotic ethnic clothing and it had no effect on the performance of Räpina singers whatsoever.

At a folk festivity in Tallinn there was a farcical situation with the Seto clothes. They had not procured Seto clothes this time even though they had promised to perform at some garden party in Kadriorg in ethnic clothing. So there was nothing else to do but to borrow ethnic clothes from the brass ensemble of Iisaku and perform in these as if they were their own. (Karheiding 1925: 71)

Introducing foreign culture in exotic ethnic clothing was clearly related to the widely common practices of representing foreign and "primitive" cultures. According to the extant sources, at least some members of the Tooste choir have discussed their activities in this light. The most remarkable example of this is a letter from Hermann Julius Schmalz (1870-1945), member of the choir, to Jakob Hurt. As it appears, Schmalz tried to organise a visit to St. Petersburg after the successful performances at Vanemuine and Estonia theatres in 1886. Schmalz had chosen the famous Ciniselli Circus as the most suitable place for a concert and so he proposed Jakob Hurt, then a pastor residing in St. Petersburg, that he helped organise the "Seto choir" performances for a month in-between the circus shows.

As I was visiting folk festivities with my "Seto" choir last year, in 1886, upon the recurrent requests of the societies of the Estonia Theatre in Tallinn and Vanemuine Theatre in Tartu, entertaining people with the songs and dances of Setos, it appeared that the people liked the said songs and dances particularly well as the ovations would not stop after each performance! The newspapers of Tallinn highly praised Setos as well. Realising that, I was suggested by many important men to make this very entertaining and interesting humour available to audiences in larger places; among others the Estonian societies in St. Petersburg were mentioned. [---]

He advised me: I should try to make a deal with the Ciniselli Circus in the capital. He said: there were often various people performing ethnic songs and dances in their ethnic clothing! It could be possible - if a deal was made with the director - that we would be accepted as part of the circus for a few weeks and be paid a worthy fee for our efforts. [---] 
Would you be so kind as to help me by handling the negotiations with the director of Ciniselli and pass on to him our requests and conditions which would be more or less the following: He would include us at least for a week - even better if for longer - in his circus department and we would perform every night - between other shows - with our Seto songs and dances and would be paid a certain share, or percentage, of the night's profits. [--- ${ }^{20}$ (EKLA, f 43, m 20:51, 1 1/1)

Schmalz regarded the Seto performances as an exotic attraction, the value of which for him was that it would "paint a truthful picture of the life of our ancestors and of olden times, because, as it is known, Setos come from the ancient tribe of Estonians" (ibid.). Thus Schmalz was informed of the theories of the time that viewed Setos as Estonians on a lower level of development. Setos (or, to be more precise, Estonians dressed as Setos) personified the "awkward" relatives stuck in the archaic "level of development" but possessing exposition value as something foreign and exotic. In his letter to Hurt, Schmalz describes the pleasant attention and havoc that the choir had caused by performing as Setos in Estonian towns.

I certainly hope that the attendance at the circus would be much greater if an authentic Seto coat and a peculiar person therein performed there. We saw how the Seto clothing caught attention when people were curiously watching us on the streets of Tallinn; the townsfolk slowed down the horsecars so that they could look at the white Seto coats and patterned knee-socks... [---]

We also often laughed at how the townsfolk spoke about us among themselves; some said: 'Es sind kleinrussländer,' while others said "Finnen" oder "Mongolen". We heard also many other names about us, such as "Caucasian mountain people”, etc. [---] (EKLA, f 43, m 20:51, 1 1/2, 1/3)

\section{HUMOROUS DIALOGUES IN A PECULIAR LANGUAGE AND "ARCHAIC" SONGS}

Funny dialogues acted out in the Seto language, or imitating the language, sometimes expanding to the scope of a play, probably shared an equal role with music in the programme of southern Estonians performing as Setos. The "Setos" and the "Seto language" were presented to the audiences as a curiosity next to other entertaining attractions. Besides Setos, a party programme would feature, for instance, a "contortionist (a boneless man)" or a strongman 
"who can lift 3 men with one arm and walk around on the stage holding them overhead", etc., and the event concluded with "grand fireworks" (Postimees 1897b: 4). It is understandable that the Seto dialogues performed in this context served entertaining purposes and had to be funny, easily comprehensible, and present Seto culture in a simplistic (or often clearly mocking) manner to capture the hearts of Estonian audiences.

It is probably not a coincidence that the most famous author of popular books in the Seto language, Hermann Julius Schmalz, grew out of this Tooste choir. ${ }^{22}$ At the turn of the century, Schmalz published five books in the Seto language (Schmalz 2013), the most famous of which is a ballad of the tragicomical adventures of a Seto man, titled Töganitsa Höödo naise wõtmise ja tarõ palamise lugu ('The story of Feodor of Töganitsa, his finding a wife and the burning house', 1899). ${ }^{23}$ Schmalz's texts are probably closely related to the oral performance, that is, all of these contain direct and indirect references to the performances of the texts. ${ }^{24}$ The genre of the texts varies but all contain abundant humorous dialogues and reflect relevant topical events. It is quite possible that some of these works were performed at the concerts of Räpina "Setos" from Räpina Parish. The language used by Schmalz clearly shows the specific features of the Räpina variety (e.g., lengthening or monophthongising of diphthongs), but he has also added many Russian loan words to make it sound more "Seto-like", and also for the comical effect. The humorous "Seto books" by Schmalz make rather rude jokes about Setos, who are depicted as cheerful and active "children of nature" who have an opinion about everything but whose ignorance and poor level of education leads them to disasters. In a newspaper advertisement of one of his Seto books, Schmalz introduces Setos and their language as follows: "The personality of a Seto is the same as that of Kilplased, while the dialect is funny in itself"25 (Schmalz 1901: 4), which well summarises the programme and rhetoric of his works.

Schmalz's highly popular, undemanding and simple books probably caused a certain boom in the Estonian book market in the early twentieth century, when several humorous books in the Seto language were published in succession. ${ }^{26}$ The books in the Seto language were closely connected with the Seto storytelling tradition, and in many cases it is difficult to tell whether a text is a piece of folklore recorded in writing or a new creation. The most famous Estonian author to follow this trend was artist and writer Jaan Vahtra (1882-1947), who for a short while (in 1906) travelled together with Schmalz's "Seto choir". Vahtra published a collection of humorous tales on the Seto theme, titled Seto nali ('Seto joke', 1905), and the inspiration behind these was very likely the 
performed plays in the Seto language. ${ }^{27}$ One play performed by the Räpina parish choirs acting as Setos has survived in manuscript form and is even older than the "Seto" texts by Schmalz and Vahtra - Mardisandid: Settu naljamäng lauludega kolmes vaates ('Martinmas Mummers: Seto farce with songs in three acts', 1886 $)^{28}$ by the later leader of Mehikoorma singing and drama society, Viido Kiudosk. The chronicles of the Tooste singing and drama society passingly mention the performance of this play:

On two evenings in the month of February 1887, the Toosikatsi choir performed a play in the Vanemuine theatre hall in Tartu. They played the farce 'Martinmas Mummers', poeticised by Kiudosk in the Seto dialect. Krumpann's zither ensemble played during the intermissions. On the first evening the audience crowded the hall, on the second evening the attendance was more modest. The audience seemed to like the play and acting a great deal, showing it with their loud laughter and applause. The cast included: Joosep Puksov, Joosep and Jakob Songi, H. Andressoon, Peeter and Kustav Kirotar, Peeter Ritsland, H. Zernask, Leena Kiisk, and A. Nass. The event ended with dancing. Although profits of the evening were good, Krumpmann cheated the actors with their pay. (EKLA, f 169, m 152:1, 1 43)

The unpublished manuscript of Viido Kiudosk's play with songs, Martinmas Mummers (see EKLA, f 151, m 10:5), is an important source in studying performances of Seto culture because the manuscript concludes with notations of the "Seto songs" performed as part of the play. Even so, these are not the only traces of the repertoire of "Seto choirs", because the second reprint of Schmalz's humorous pamphlet, Mia tõmokraat tähendäs ('What a democrat is') in the Seto language also contains the notation of a popular south-Estonian two-part song Kulla imä, zirgu imä ('Dear mother, dear birdie'); also, the choir singing repertoire of the region is represented by the manuscript of Neli näitelaulu ('Four songs from plays') by Viido Kiudosk. ${ }^{29}$ The Martinmas Mummers play, however, includes a number of songs - altogether 11 notations. The majority of these so-called Seto songs are, in fact, rather regular songs of the earlier type from Räpina Parish. Some songs are presented as an arrangement for four voices, for the others only the lead singer's part and its repetition are included, whereas the repetition is often given as a choir part. While some of the polyphonic adaptations are clearly representative of the newer choir singing tradition, i.e. they are not related to the traditional polyphonic styles known in the Seto region or southern Estonia, other songs seem to represent a slightly adapted version of unique polyphony of Räpina Parish. ${ }^{30}$ 
In his letter to Hurt, Hermann Julius Schmalz also promotes the songs of the "Seto choir" as three- or four-part songs. Lyrics of the songs played an important role and Schmalz has described these as "interesting", "unique", and "funny". Depending on the contents, the songs were sung either by a male choir or a mixed choir.

Dances are usually performed in two ways: accompanied by an instrument (accordion) or by singing. The song is written for 3 to 4 voices, has very interesting lyrics, and those who can understand them find them truly unique and funny to listen to. While I visited the folk festivities only with the male choir, I would now like to take some women along as well because singing and dancing is much more appealing with them. I would take about 8 to 10 people. ${ }^{31}$ (EKLA, f 43, m 20:51, 1 1/3)

In addition to the adaptations of traditional songs from Räpina, also popular songs by local composers were performed at such concerts. The repertoire of Estonian popular songs still includes some songs on the Seto theme composed by Schmalz (see Kõivupuu 1999; Kolk 2013). Jaan Vahtra recalls in his memoirs how they sang with Schmalz's "Seto choir” the song Setokõsõ sõidiva ('Setos took a ride'), one of Schmalz's own creations, and an older folk song well known in Võru County, Tuup viina tuudi, tuudi ('A stoup of vodka was brought').

I remember that the mixed quartet performed such peculiar songs as: 'Setokõsõ sõidiva' and 'Tuup viina tuudi, tuudi'. Let me note at this point that the former was purely Hermann Juulius Schmalz's creation, both the lyrics and the tune. The second song is most likely an old folk song from Võru County, with lyrics adapted, revised, and improved by Schmalz. (Vahtra 1935: 193-196)

The song lyrics harmonised with the humorous dialogues, and were often used for a comical effect. By the end of the nineteenth century, folk songs and their adaptations had become a valued national heritage for the nationally minded audience. The popular national repertoire would include music of widely varying age and origin and authored creation, but was highly valued among Estonianminded audiences. The reviews of the Räpina choirs performing as Setos also indicate that these concert shows in ethnic clothing were popular largely due to their national character and supposed "authenticity". For example, following a performance in Tartu, a reviewer commended the use of folk tunes and the modern polyphonic arrangement characteristic of folk songs. The practical purpose and humour of "ancient" song texts were once again mentioned in relation with the Seto choir. 
It is particularly gratifying that Estonian folk tunes are already being sung by performers. Estonian folk tunes, somewhat expanded and with other voice parts added, were sung by the Kõrveküla mixed choir when they won their first prize. These funny but also practical folk songs were sung by the Seto choir who were highly praised for that. (Postimees 1886b: 2)

\section{ON THE CRITICAL RECEPTION OF THE “SETO” CHOIRS}

According to the information that could be traced in the newspapers of the period, and the choir's chronicle, at the turn of the twentieth century the choir of the Tooste singing and drama society, or its reduced ensembles, performed, in Seto clothing, with great success at the major folk festivities of the Vanemuine and Estonia societies in Tallinn and Tartu. They also appeared on stage elsewhere in the country, reportedly in Pärnu, Viljandi, Kuressaare, Valga, Rakvere, Tapa, Ambla, Jõgeveste, Äksi, Voldi, Tõrva, Kaagvere, Jõgeva, Põltsamaa, Kavastu-Koosa, Krüüdneri, Ulila, etc.

While the wide range of places where the choir performed indicates that the performances were profitable, the choir was not always very amicably welcomed. The negative critique was mostly targeted at the old and boring songs on the one hand (even though other critics praised these as ancient and "authentic"), but on the other hand the discontent may have been caused by the disrespect for the Seto people and the fact that there were no actual Setos in the advertised Seto choir.

A typical critic who was not familiar with older folk songs and the arrangements complained that the songs were too long and repetitive and the tunes were monotonous. The old songs were thought to be boring and gloomy. The reviewer of the concert at Tapa had expected to hear newer songs and wondered why such humorous lyrics were sung to sombre melodies.

The Seto brothers gave a concert here on the 12th day of this month. Since it was organised late in the evening, when it was already dark outside, not many people were attending. One could be somewhat satisfied with the performance of the songs, but since the melodies were like old melodies tend to be, that is, very monotonous, and the same song words were repeated over and over, and the words were funny but the melodies sombre, they did not go at all well together. The concert would have been much livelier and more popular if Mr. Schmalz had bothered to include some newer songs among the old ones. From the very first songs, the audience 
made too much noise with clapping and stomping, so that the performers thought that they were asked for an encore and, for no reason, repeated several songs, which was very awkward and embarrassing to hear. [---] It would probably have been better if the choir leader had excluded the tale about the death of the gelding and the burden of sin entirely from the performance. (Postimees 1899: 3)

Along with the repertoire, the criticism also targeted the performance style. Apparently, performing as Setos involved making strange gestures or acting out and humorous mimicking of certain physical "Seto" qualities. Many reviewers describe how the choir performed "Seto songs" to peculiar movements. Depending on the critic, it was referred to as funny or ridiculous stupidity. Reviewers of the concert in Valga, for example, have many positive things to say about the choir but are critical of the "boring" old melodies and certain lapses in taste. We learn about the songs in the repertoire and that the singers moved in a strange way during the performance.

In the first part, the songs and especially dances were received with great ovations. In the second part, the distasteful ending of the song 'Lü̈ iks pille peeno huuli' ['Play the instrument, gentle lips!'] put off the audience, whereas the songs 'Pini handa höörätõlli' ['The dog swirled its tail'] and especially 'Keresse Ivvo ruuna hingeheitmise lugu' ['The story of how Ivvo of Keresse's gelding died'] with their very peculiar words and also funny melodies drew a never-ending applause until they were repeated. The concert is worth visiting for this one song only. In the third part, the audience wished that the verses of the song 'Neiukõsõ noorõkõsõ' ['Dear maidens, the young ones'] would be shorter, because with such length and the rather unvaried melody it seemed boring. But all the more interesting was the following song 'Rikas raha raputôlli' ['The rich man showed off his money'] because of the strange bodily movements of the singers. (Eesti Postimees 1897: 2)

Besides the criticism of the choir and the performance, some also concerned themselves with the fact that the choir performed as Setos. The critique was not only targeted at the representation of Setos and ethical issues but was prompted by the fact that the choir's performing as Setos was for some reason found inauthentic. A reason for that could have been not Seto-like (or too fancy) costumes, poor use of the Seto language, or dancing that did not resemble that of Setos. 
On 13 August, a concert of the so-called "Seto mixed choir of Räpina" conducted by Mr. H. J. Schmalz was held at Woldi. [---] The singers were supposed to perform in Seto ethnic clothes, but they appeared on stage in fancy boots and posh store-bought hats. The speech and language of the characters revealed that most of them do not even know who Setos are or how they live. [---] The song 'Keresse Iwwo ruuna hinge heitmise lugu' ['The story of how Ivvo of Keresse's gelding died'] went rather nicely. On the other hand, the "authentic Seto dance" had nothing in common with Seto dancing. All in all, the concert was not particularly entertaining or instructive, which justifies the general disappointment of the spectators after the concert. (Postimees 1900: 3)

Jaan Vahtra's memoirs include an incident of how secondary school students, who were present at the 1906 concert in Mulgi region, had shouted to the "Setos" with hostility: "Go back to your Seto region!" When an event called "A funny concert of Setos" was organised at Väike-Ulila manor in 1900 and it was advertised in the local newspaper Olevik (The Present), an anonymous reader sent the newspaper an angry note in which he "disclosed" that the clowns who performed all over the country as "the Seto choir of Räpina" were neither Setos nor came from Räpina. The reader, probably from Räpina himself, found it concerning that Räpina Parish was represented by the "crazy" Schmalz with his group, who in such an inappropriate manner mixed up the culture of Lutheran Räpina people with the "backward" Seto culture.

But since they are boasting that they come from "Great Räpina" and since the "Seto choir of Räpina" is currently giving concerts over there, I dare to say some words in this matter. To put it briefly, there is neither "Seto choir" nor any other public "choir" in Räpina at the moment. Räpina is not part of the Seto region, here people neither speak the Seto language nor wear Seto clothes. It is not at all right that some man from Räpina has brought along a man from Yuryew (Tartu), a Gypsy, or someone of other origin, and they parade together under the famous name of "Seto choir of Räpina". The leader of this "choir of frauds" should leave the name "Räpin" be and call his choir anything else that he chooses. (Uus Aeg 1899: 3) 


\section{IN CONCLUSION}

\section{Performing as Setos: Modern nationalism and ethnographic surrealism}

At the beginning of the twentieth century, several manifestations of folklore flourished in Estonia, people viewed borrowed cultural phenomena critically, the studying of early cultural tradition was initiated, and attempts were made to construe "authentic" Estonian folk music and dance culture (see Lippus \& Steinbach 2009: 114ff.; Kapper 2013). Initially it meant embedding elements picked from the early tradition, which for some reason were considered Estonian, into German or Russian style "European" music, dancing or art. In order to finance national museums and societies, however, people started to organise popular fundraising events and concerts, which among other acts featured country people in ethnic clothes, who had been brought to town to perform oral rural music tradition in a new urban setting (see Pulst 2014; Õunapuu 2011). ${ }^{32}$ Institutions involved in studying folklore also took part in such activities as they started to define and safeguard the line between adapted folklore and national and "genuine" tradition.

Who is qualified to perform culture is a heavily loaded question that has elicited varying responses throughout history (see Kirshenblatt-Gimblett 1998: $75 ; 1988)$. In the late nineteenth century, when the choirs of Räpina Parish travelled around performing as Setos, the boundaries of genuine tradition, a revival, fakelore, or elite culture were not exactly where they became established over the course of the twentieth century. Modern phenomena, such as the budding Estonian national awareness and a search for the roots of Estonian culture, the processes of defining its boundaries and establishment, became mixed with earlier phenomena, such as the colonialist demonstration and abuse of exotic cultures for entertaining purposes. In the development of Estonian national culture, the choirs of Räpina Parish represented an important institution a singing choir and a cultural society consisting of Estonians; and via these organisations par excellence, the national movement reached from the elite to the "ordinary" people (see Jansen 2007: 406ff.). On the one hand, these choirs from a peripheral location emulated the modern and national choir-singing and society movement, which took place elsewhere in Estonia, but on the other hand they imitated the age-old and familiar models of performing colonialist foreign cultures or the freak shows at fairs and circus performances.

The exoticising and entertaining or commercial demonstration of the culture of Setos, close neighbours of Estonians, did not cause major ethical problems at 
the time, and it was considered sufficiently presentable. Setos were still largely illiterate at the time and they had no "voice" to comment on or criticise the performance or representations of their culture (see Kalkun 2015). While today the issues of cultural appropriation and presentation of small and indigenous peoples continue to be relevant and very acute, performing as Setos in the late nineteenth-century Estonia prompted no major discussion. Over the course of the twentieth century, the traumatic histories of small and indigenous peoples became particularly topical, constantly triggering issues of rights and ethics - for example, who are allowed to sell their music as Tibetan music (Upton 2002); who is permitted to wear the traditional Sami clothing and represent the Sami (Valkonen 2009); to whom belongs the Nordic heritage in Scandinavia (Aronsson \& Gradén 2013), and to whom belongs Seto folklore (Kalkun 2015; Kuutma 2012, 2009a, 2009b). However, in the nineteenth century these questions were not pondered on.

In a way, the performing of the Räpina choirs as Setos could be viewed as a very modern phenomenon. Folklorist Marju Kõivupuu (see Kõivupuu 1999) has referred to Schmalz's "Seto choir" as the first modern-day folk ensemble on Estonian soil. However, performing foreign folklore makes this innocent folk ensemble quite different from today's Estonian folk ensembles, who work hard to show their "own", inherited tradition. In the shows of the Räpina choir, the Seto culture was approached in a surrealistic fragmentary and contorted manner, representing the aesthetics that values fragments, curious collections, and unexpected juxtapositions (see Clifford 2002 [1988]: 117ff.), which was probably effective as a demonstration of an "exotic" and "peculiar" culture. The Estonians performing as Setos, who travelled in the nationally awakening Estonian towns and rural areas, making crude jokes, speaking a strange language, and wearing unusually matched traditional Seto clothes, in a sense associate with the term "ethnographic surrealism" coined by James Clifford. The "Setos" from Räpina creatively combined phenomena that were no longer acceptable a few decades later. The utopia they construed of the Seto culture combined the past and the future and operated in the commercial space between folk culture and elite culture.

Cultural appropriation and demonstrations of other cultures are always related to practical, ethical, political, and economic issues (see KirshenblattGimblett 1988: 149). The advertisement of the first-time introduction of Setos on stage by the Räpina choirs was, in fact, deception. It is possible that the general Estonian public was not prepared to see Setos without the added dressing of entertainment, and Setos themselves were not showcasing or exporting their "first life" of culture for outside audiences at the time. The early performances 
of the Seto singing culture by Räpina parish choirs represent the searches coinciding with the period of national awakening in Estonia and the curious detours from own national heritage to explore the close Others, the Seto people, though in a very peculiar and alienating manner. Digging through the garbage of history enables us to date the beginning of the folklore movement in Estonia to an earlier time but also adds to the context of the early academic representations of Seto culture.

\section{ACKNOWLEDGEMENTS}

This study was supported by the Estonian Ministry of Education and Research (IUT 22-4, "Folklore in the Process of Cultural Communication: Ideologies and Communities"), and by the European Union through the European Regional Development Fund (Centre of Excellence in Estonian Studies).

\section{NOTES}

1 In 2002, the Seto Council of Elders declared Setos as a separate people. In Estonia, there is a tendency to interpret the Setos as a segment of Estonians. Russia recognises Setos as an ethnic minority and, for example, unlike Estonian censuses, Russian censuses give Setos an option to identify themselves as Seto by ethnicity. Similarly, the Seto language has been generally viewed as a special variety of the South-Estonian dialect. Today, however, even Estonian linguists agree that Seto is a language, not a dialect. The Setos themselves regard it as a separate language.

2 Today, next to the Seto polyphonic singing culture, the other cultural phenomena related to Estonia, included in the UNESCO Representative List of Intangible Cultural Heritage of Humanity, are the song and dance celebrations in Estonia, Latvia, and Lithuania, the Kihnu cultural space, and the smoke sauna tradition in Võru County.

3 Friedrich Reinhold Kreutzwald, who was among the first authors to write about Seto culture, mentions with pride in his 1848 article "Reports on folk songs among Estonians of the Pskov guberniya" that he was one of the first to place his scholarly foot on the surface of this nearby terra incognita (Kreutzwald 1953). The 1903 fieldwork in the Seto region, conducted by Jakob Hurt as a stipendiary of the Imperial Geographical Society, resulted in an article on Estonians in the Pskov region or Setos, published in Russian and German (Hurt 1903), and became a seminal text that strongly influenced all subsequent discourses about Setos (see Kalkun 2015).

${ }^{4}$ Seto multipart singing differs from the polyphonic singing known in the neighbouring areas, and the early Seto music features highly rare scales, in which semitone intervals alternate with three semitone intervals (see Pärtlas 2010; Ambrazevičius \& Pärtlas 2011; Pärtlas \& Oras 2012). This is why Seto music is very different from the neighbouring Estonian or Russian folk music also in objective terms. 
${ }^{5}$ Folklorist Kristi Salve, for example, asks: "When we read about the singing of Seto women in Germany or Russia, on the stages of Paris or Helsinki, it inevitably makes one wonder what they actually represent, what they symbolise - the ancient singing culture of their ethnic group or, perhaps, even that of the whole Estonia" (Salve 2000: 55).

${ }^{6}$ In Estonian linguistics Võro and Seto languages have been traditionally considered varieties of the Võru dialect.

7 It must be noted here that Setos' poor literacy in the nineteenth century does not mean that at that time Seto culture remained unaffected by the written culture, at least to some extent (see Toomeos-Orglaan 2015; Kalkun 2015).

8 The three choirs of Räpina parish were related to each other and some of the members sung in different choirs at different times. Viido Kiudosk, for example, was the conductor of the Mehikoorma choir, but his plays were performed also by the Tooste choir. At different times, journalists referred to choirs of different compositions by the name "Räpina choir" or "Seto choir", and some choirs, indeed, changed their name in the meantime. The aim of this article is not to determine the precise and detailed relations between the different choirs but to observe the phenomenon in more general terms.

9 The anthology was titled Setukeste laulud ('Seto Folk Songs') but the subtitle (Old Songs of Estonians from Pskov with Songs from Räpina and Vastseliina Parishes) explained that next to the songs of Setos, who are referred to as Estonians from Pskov, it included also folk songs from the Livonian parishes of Räpina and Vastseliina.

${ }^{10}$ Usstav's letter to Kallas, 16.06.1911. It appears that the Seto choir under Usstav's supervision had continued to be active in the 1920s, after Usstav had moved from the Seto region to Antsla in Võru County. In 1921, Usstav writes to Kallas: "In May I planned on going to Finland with the 'Seto choir' but there were obstacles, so that we will only perform in Tallinn (Estonia Concert Hall) on 18 April and in Haapsalu on 20 May" (Usstav's letter to Kallas, 12.05.1921, EKLA, f 186, m 76:8, 1 4/5).

${ }^{11}$ In accordance to the customs of the time those heterogenic and probably black-skinned companies were called neegrid (Negroes). In newspapers nothing specific about the origin or ethnic makeup of such groups can be found; usually they were just vaguely named "Negroes from Africa", "Negroes from America" or just "Negroes".

${ }^{12}$ Such opinions were in accordance with the general image of Africa in the nineteenthcentury Estonia (see Hiiemaa 2009).

13 The Estonian Cultural History Archives hold the chronicle of the choir from the years 1881-1898, titled "The protocols of the Toosekatsi singing and drama society choir".

${ }^{14}$ The reviewer refers to the conflict between the two figures of the Estonian national movement and editors-in-chief of competing newspapers, Carl Robert Jakobson and Ado Grenzstein, in which the former represented more radical nationalism and the latter a more lenient course (see Raun 1981).

15 The reviews of the performances of choirs dressed as Setos often stressed the fact that it was Setos' first visit. For example, an 1897 review of a concert in Viljandi, southern Estonia, reads: "The second day of the Viljandi exhibition was a great success. [...] On 8 September, the final day of the exhibition, the people of Viljandi and other guests 
were entertained by a Seto choir, led by Mr. Schmalz, with their fascinating Seto songs and dances that were seen here for the first time" (Postimees 1897a: 3 ).

16 The choir singing programme included, among other music, songs by Estonian composers - Nü̈̈d üles, vene alamad ('Arise, you subjects of Russia') by J. V. Jannsen, Oh laula ja hõiska ('Oh, sing and rejoice') by Karl August Hermann, and Mu suurem rõom on isamaa ('Fatherland is my greatest joy') by Peter Laredei, on the lyrics of Ado Grenzstein - but also Estonian adaptations of songs by German composers, such as, for example, Kõla kaugel ('Sound afar') by Friedrich Wilhelm Sering.

17 "At the folk festivity one could also bear witness to how the Estonian national costume is held more and more in esteem. Particularly beautiful was the national costume worn by the soprano singer from Aru-Karijärve, and we praise it as a fine example. The maidens of the Seto choir were also wearing very beautiful and unique ethnic costumes." (Postimees 1886b: 2)

18 "On 17 August this year [1886], the Toosikatsi choir went to the folk festivity in Tartu, where they sung Seto songs that were received with the greatest enthusiasm. They also took part in a singing contest, winning the third prize with the song Nüüd vennad kärmeste [Come quick now, brothers!] by Becker, but the sum of the prize is not yet known. The choir has received 15 roubles from the Vanemuine Society for travelling. The master of the Luke manor, M. Johanson, has given the Setos 10 roubles as a token of his gratitude, so all in all they received 25 roubles from Tartu..." (EKLA, f 169 , m 152:1, l13p, 14).

${ }^{19}$ A letter by Viido Kiudosk to the festival organising committee (12 May 1880, EKLA, f 76, m 2:3, 1 24/47), see Põldmäe 1976: 190.

${ }^{20}$ H. J. Schmalz's letter to J. Hurt, 28.01.1897.

${ }^{21}$ H. J. Schmalz's letter to J. Hurt, 28.01.1897.

${ }^{22}$ For further information on Schmalz's life, see Aabrams 2013, 2016; Kõivupuu 1999, 2013.

${ }^{23}$ In addition, there is a manuscript of the play in the "Seto language" or its project (EKLA, f 169, m 149:21).

24 The Estonian Folklore Archives store songs containing the text of Schmalz's Töganitsa Höödo and collected from the Seto region and southern Estonia, e.g., EKRK, Fon 50 B12, Udo Kolk from Nikolai Tirp, 46, Seto, Laossina village (1968); EKRK, Fon 56 A9, Udo Kolk from Leida Tarend, 61, Seto, Matsuri village, originally from Vyporsova village (1969); RKM, Mgn II 3324 (3), Heiki Silvet from Hilda Ilves, b. 1909, Kahkva urban settlement, Räpina Parish (1980); ERA, DAT 23 (4), Anu Korb from Lonni Ilves, b. 1925, Zolotaya Niva village, Okoneshnikovsky District, Omsk Oblast (1995), ERA, CD 32 (31); Ahto Raudoja from Maanu Reino, 74, Kambja parish, originally from Tartu (1997). The entering of the text into oral singing tradition can be explained probably with the clearly oral nature of Schmalz's original text.

${ }^{25}$ Kilplased ('Gothamites') are a fictitious people in an allegorical satire by the Estonian author F. R. Kreutzwald (1857, adaptation of the German chapbook Der Schildbürger by G. O. Marbach) and their name has been adopted into general use as a synonym of a simplistic or ignorant and stubborn person. 
${ }^{26}$ More noteworthy among such simple works of literature were, for example, Peeter Friedrich Kõiv's tale Kuis Kärekülä seto Pihkvah jesätse kassi prohvusõ peräst parki saasõ ('How a Seto from Kärekülä village got beaten up in Pskov over a bloody tomcat', 1902) and the plays by Arnold Kõiv that were published somewhat later - Warga ôhwakõ: setu nali ühes vaatuses ('The bull calf of a thief: A Seto farce in one act', 1931), and Kooluheng: Ühevaatusline nali ('Spirit of a dead person: A farce in one act', 192?).

${ }^{27}$ Jaan Vahtra's memoirs entail a passage which confirms that he has read out these texts at the performances of the "Seto choir": "In the next part I took the stage. I read out a funny Seto tale from my collection of Seto tales and then the stories "Jesus travelled along the river, Holy Mary along the shore" and "Toomas ate, Toomas drank" from [Jakob] Hurt's Setukeste laulud ('Seto Folk Songs') (Vahtra 1935: 199-205).

${ }^{28}$ Manuscript in the Estonian Cultural History Archives (EKLA, f 151, m 10:5).

${ }^{29}$ Kiudosk's four songs from the play stand out because they are mainly in Estonian (including only a few dialogues in the South-Estonian dialect) (EKLA, f 181, m 9:12).

${ }^{30}$ Since the activity of the choirs of Räpina Parish falls into the period when the first folk songs of the parish were being recorded, it is not entirely certain to which degree the polyphony of Räpina Parish was an "invented" tradition, i.e. to what degree the singing of "Setos" as part of the choir singing tradition of Räpina Parish influenced the local folk tradition. Two three-part songs from Viido Kiudosk's Martinmas Mummers, however, have been included in the prestigious edited anthology, Eesti rahvalaule viisidega ('Estonian folksongs with melodies'), compiled by Herbert Tampere, as "authentic" examples of the song repertoire sung in Räpina (Tampere 1965: 51, 193).

${ }^{31}$ H. J. Schmalz's letter to J. Hurt, 28.01.1897.

${ }^{32}$ In Finland, similar phenomena of bringing "authentic" folk singers to perform in cities and add an ethnic touch to events occurred at an earlier time (see Knuuttila 1994; Tenhunen 2006: 81ff.).

\section{ARCHIVAL SOURCES}

\section{Estonian Folklore Archives at the Estonian Literary Museum}

EKRK, Fon - sound recordings of the Chair of Literature and Folklore at the University of Tartu

ERA, DAT - digital audio tape recordings of the Estonian Folklore Archives

ERA, CD - CD-collection of digital audio recordings of the Estonian Folklore Archives

RKM, Mgn II - open-reel tape recordings of the State Literary Museum

\section{Estonian Cultural History Archives at the Estonian Literary Museum}

EKLA - manuscript collection of the Estonian Cultural History Archives 


\section{REFERENCES}

Aabrams, Vahur 2013. Schmalzi "setoraamatist" kultuuriloolisõl taustal. [On Cultural Historical Background of Schmalz's “Seto Books”.] In: Kristiina Tiideberg (comp.) Töganitsa Höödo, Alatarõ Hipo ja tõsõ’: Hermann Julius Schmalzi juttõ. Seto kirävara, 5. Värska: Seto Instituut, pp. 165-175.

Aabrams, Vahur 2016. Hermann Julius Schmalz (1870-1945): Luuletaja, jutu- ja näitekirjanik, muusik, muusika- ja keeleõpetaja. [Hermann Julius Schmalz (18701945): A Poet, Prosaist, Playwright, Musician, Music and Language Teacher.] In: EEVA. Eesti vanema kirjanduse digitaalne tekstikogu. Available at https://utlib. ut.ee/eeva/index.php?lang=et\&do=autor\&aid=658, last accessed on March 30, 2017.

Ambrazevičius, Rytis \& Pärtlas, Žanna 2011. Searching for the "Natural" Origins of the Symmetrical Scales: Traditional Multipart Setu Songs. Journal of Interdisciplinary Music Studies, Vol. 5, No. 1, pp. 1-17. Available at http://www.musicstudies. org/jims201151/Ambrazevicius_JIMS_11050101.pdf, last accessed on March 30, 2017.

Aronsson, Peter \& Gradén, Lizette (eds.) 2013. Performing Nordic Heritage: Everyday Practices and Institutional Culture. Farnham: Ashgate.

Clifford, James 2002 [1988]. The Predicament of Culture: Twentieth-Century Ethnography, Literature, and Art. Cambridge, Mass. \& London: Harvard University Press.

Eesti Postimees 1882 = Uuemad sõnumid. [Recent News.] Eesti Postimees ehk Näddalaleht: ma- ja linnarahvale, No. 11, March 10, p. 4. Available at http://dea.nlib. ee/JQ/fullview.php?frameset=3\&showset=1\&wholepage=suur\&pid=s857123\&n id=73889, last accessed on March 30, 2017.

Eesti Postimees 1897 = Uuemad sõnumid: Valgast. [Recent News: From Valga.] Eesti Postimees ehk Näddalaleht: ma- ja linnarahvale, No. 38, September 18, p. 2. Available at http://dea.nlib.ee/JQ/fullview.php?frameset=3\&showset=1\&wholep age $=$ suur\&pid $=$ s476639\&nid $=252776$, last accessed on March 30, 2017.

Hagu, Paul 1978. Setude etnogenees agraartavandi valgusel. [Ethnogenesis of Seto People in the Light of Agrarian Traditions.] Keel ja Kirjandus, No. 10, pp. 616623. Available at http://www.digar.ee/arhiiv/et/perioodika/34851, last accessed on March 30, 2017.

Hiiemaa, Karin 2009. Aafrika imago eestikeelses trükisõnas. [The Image of Africa in Estonian Printed Word.] Tartu: Tartu Ülikooli Kirjastus.

Honko, Lauri 1990. Folkloreprosessi. [The Folklore Process.] Sananjalka, No. 32, pp. 93-121.

Hurt, Jakob 1903. Über die Pleskauer Esten oder die sogenannten Setukesen. In: Anzeiger der Finnisch-Ugrischen Forschungen. Band III, Heft 3. Helsingfors: Harrassowitz, pp. 185-205. Available at http://www.digar.ee/arhiiv/et/raamatud/50291, last accessed on May 30, 2017.

Hurt, Jakob 1904. Setukeste laulud. Pihkva-Eestlaste vanad rahvalaulud, ühes Räpinä ja Vastseliina lauludega. Ezimene köide. [Seto Folk Songs: Old Songs of Estonians from Pskov with Songs from Räpina and Vastseliina Parishes. First volume.] Helsingi: Soome Kirjanduse Selts. 
Hurt, Jakob 1989. Mida rahvamälestustest pidada. Artiklite kogumik. [What to Think about Folklore. Collection of Articles.] Compiled by Ülo Tedre. Tallinn: Eesti Raamat.

Jääts, Indrek 1998. Setude etniline identiteet. [The Ethnic Identity of the Setos.] Studia ethnologica Tartuensia 1. Tartu: Tartu Ülikooli etnoloogia õppetool.

Jansen, Ea 2007. Eestlane muutuvas ajas: Seisusühiskonnast kodanikuühiskonda. [Estonians in a Changing World.] Tartu: Eesti Ajalooarhiiv.

Kalkun, Andreas 2015. Seto laul eesti folkloristika ajaloos: Lisandusi representatsiooniloole. [Seto Singing Culture in the Studies of Estonian Folklore: A Supplement to the History of Representation.] Eesti Rahvaluule Arhiivi toimetused / Commentationes Archivi Traditionum Popularium Estoniae 33. Tartu: Eesti Kirjandusmuuseumi Teaduskirjastus.

Kapper, Sille 2013. Estonian Folk Dance: Terms and Concepts in Theory and Practice. Folklore: Electronic Journal of Folklore, Vol. 54, pp. 73-96. http://dx.doi. org/10.7592/FEJF2013.54.kapper.

Karheiding, J. 1925. Mõnda koorilaulu minevikust Räpinas. (Kokkuvõte Räpina laulukursustel peetud kõnest 1. veebruaril 1925. a.) [On the History of Choir Singing in Räpina. (A resume of a speech held at a singing course in Räpina, 1 February 1925).] Eesti Lauljate Liidu Muusikaleht, No. 5, pp. 71-72.

Kirshenblatt-Gimblett, Barbara 1988. Mistaken Dichotomies. The Journal of American Folklore, Vol. 101, No. 400, pp. 140-155. http://dx.doi.org/10.2307/540105.

Kirshenblatt-Gimblett, Barbara 1998. Destination Culture: Tourism, Museums, and Heritage. Berkeley \& Los Angeles \& London: University of California Press.

Knuuttila, Seppo 1994. Pohjolan sokea Homeros: Jalo kansa ja suuri linja yhtenäiskulttuurin vertauskuvina. [Homer from the North: The Noble Folk and Monumental Line as Symbols of Common Culture.] In: Tyhmän kansan teoria: Näkökulmia menneestä tulevaan. Tietolipas 129. Helsinki: Suomalaisen Kirjallisuuden Seura, pp. 101-122.

Kõivupuu, Marju 1999. Sauna taga, tiigi ääres... ehk ühest unustatud laululoojast ja mõnda tema vennastki. [At the Pond behind the Sauna... Or about One Forgotten Songster and His Brother.] Mäetagused, Vol. 10, pp. 106-129. http://dx.doi. org/10.7592/MT1999.10.schmalz.

Kõivupuu, Marju 2013. Tsuhknast seto sõnameistri Hermann Julius Schmalz. [Estonian Hermann Julius Schmalz as a Seto Writer.] In: Kristiina Tiideberg (comp.) Töganitsa Höödo, Alatarõ Hipo ja tõsõ’: Hermann Julius Schmalzi juttõ. Seto kirävara 5. Värska: Seto Instituut, pp. 165-175.

Kolk, Udo 2013. Sauna taga, tiigi ääres: 100 aastat setu kirjamehe H.J. Schmalzi sünnist [At the Pond behind the Sauna: Centenary of the Birth of Seto Writer H.J. Schmalz.] In: Madis Arukask (ed. \& comp.) Folkloori olemust otsides. [In Search of the Essence of Folklore.] Tartu: Ilmamaa, pp. 472-479.

Kreutzwald, Fr[iedrich] R[einhold] 1953. Teateid rahvalauludest Pihkva kubermangus asuvate eestlaste juures (1848). [Reports on Folk Songs among Estonians of the Pskov Guberniya (1848).] In: K. Taev (ed.) Maailm ja mõnda. Tallinn: Eesti Riiklik Kirjastus, pp. 105-112. 
Kuutma, Kristin 2006. Collaborative Representations: Interpreting the Creation of a Sámi Ethnography and a Seto Epic. FF Communications No. 289. Helsinki: Suomalainen Tiedeakatemia.

Kuutma, Kristin 2009a. Cultural Heritage: An Introduction to Entanglements of Knowledge, Politics and Property. Journal of Ethnology and Folkloristics, Vol. 3, No. 2, pp. 5-12. Available at http://www.jef.ee/index.php/journal/article/view/9/ pdf_8, last accessed on March 30, 2017.

Kuutma, Kristin 2009b. Who Owns Our Songs? Authority of Heritage and Resources for Restitution. Ethnologia Europaea, Vol. 39, No. 2, pp. 26-40. Available at https://www.mtp.dk/details.asp?ELN=500320, last accessed on March 30, 2017.

Kuutma, Kristin 2012. Communities and the Contested Politics of Representational Ownership. The First ICH-Researchers Forum: The Implementation of UNESCO's 2003 Convention: Final Report: Maison des Cultures du Monde, Paris, France; 3 June 2012. Osaka: International Research Centre for Intangible Cultural Heritage in the Asia-Pacific Region (IRCI), pp. 42-51. Available at http://www.irci.jp/ assets/files/2012_ICH_Forum.pdf, last accessed on March 30, 2017.

Lillak, Anti 2014. Setode kujunemise kohta käivast diskussioonist. [On the Discussion Concerning the Ethnogenesis of Seto People.] Õpetatud Eesti Seltsi aastaraamat 2013 / The Yearbook of Learned Estonian Society 2013. Tartu: Õpetatud Eesti Selts, pp. 167-190. Available at http://www.ut.ee/OES/wp-content/uploads/Lillak. pdf, last accessed on March 30, 2017.

Lippus, Urve (comp.) 2008. 19. sajandi muusikaelu Eestis = Musikleben in Estland im 19. Jahrhundert. Tallinn: Eesti Muusika- ja Teatriakadeemia muusikateaduse osakond.

Lippus, Urve 2012. Klaver Eesti kodus. [The Arrival of the Piano in the Estonian Home.] Res Musica, No. 4, pp. 7-21. Available at http://www.muusikateadus.ee/wpcontent/uploads/2012/12/Lippus.pdf, last accessed on March 30, 2017.

Lippus, Urve \& Steinbach, Kadri 2009. Muusikaelu Eestis 1930. aastate lõpul. [Musical Scene of Estonia at the End of the 1930s.] In: Kadri Steinbach \& Urve Lippus (comps.) Eesti helisalvestised $1939=$ Estonian Sound Recordings 1939. Tallinn: Eesti Muusika- ja Teatriakadeemia muusikateaduse osakond, pp. 111-142.

Lõuna, Kalle 2003. Petserimaa: Petserimaa integreerimine Eesti Vabariiki 1920-1940. [Petserimaa: Integrating Petserimaa County into the Republic of Estonia, 19201940.] Tallinn: Eesti Entsüklopeediakirjastus.

Mägiste, J. 1957. Petserimaast, selle uurimisest ja setude päritolust. [On Petserimaa, Its Research History and the Origin of Seto People.] In: Bernard Kangro \& Valev Uibopuu (eds.) Meie Maa: Eesti sõnas ja pildis, IV. Lõuna-Eesti. Lund: Eesti Kirjanike Kooperatiiv, pp. 165-173. Available at http://www.digar.ee/viewer/et/ nlib-digar:276200/250397/page/172, last accessed on March 30, 2017.

Õunapuu, Piret 2011. Eesti Rahva Muuseumi loomine ja väljakujunemine. [Foundation and Evolution of the Estonian National Museum.] Diss. (PhD Thesis). University of Tartu. Available at http://dspace.ut.ee/handle/10062/18181, last accessed on March 30, 2017. 
Pärtlas, Žanna 2010. Setu Multipart Singing: Comparison of Written Sources and Sound Recordings. In: Susanne Ziegler \& Urban Bareis (eds.) Historical Sources and Source Criticism: ICTM Study Group on Historical Sources. Proceedings from the 17th International Conference in Stockholm, Sweden, May 21-25, 2008. Stockholm: Svenskt Visarkiv, pp. 227-237.

Pärtlas, Žanna \& Oras, Janika 2012. Seto traditsioonilise laulumaneeri jäljendamise eksperimendist. [Results from an Experiment in Emulating the Traditional Seto Singing Style.] Res Musica, No. 4, pp. 22-43. Available at http://www.muusikateadus. ee/wp-content/uploads/2012/12/Partlas_Oras.pdf, last accessed on March 30, 2017.

Piho, Mare 2003. Setud - Eesti sümbol? [The Seto People - A Symbol of Estonia?] In: Aivar Jürgenson (comp.) Aeg ja lugu: Esseid eesti kultuuriloost. Scripta ethnologica 5. Tallinn: Ajaloo Instituudi etnoloogia sektor, pp. 120-128.

Pildialbum 2008 = Eesti Rahva Muuseumi pildialbum = Die Postkarten des Estnischen Nationalmuseums $=$ Al'bom otkrytok Estonskogo natsional'nogo muzeia $=$ The Estonian National Museum in Pictures. Compiled by Indrek Ilomets \& Tiina Tael. Tallinn: Aasta Raamat.

Põldmäe, Rudolf 1938. Rahvakultuurist, eriti rahva lõbutsemisvormidest Setumaal. [On Folk Culture and Particularly on Merrymaking of the Seto People.] Tallinn: Eesti Rahvaluule Arhiiv.

Põldmäe, Rudolf 1969. Esimene Eesti üldlaulupidu 1869. [The First Estonian Song Festival 1869.] Tallinn: Eesti Raamat.

Põldmäe, Rudolf 1976. Kaks laulupidu 1879-1880. [Two Song Festivals 1879-1880.] Tallinn: Eesti Raamat.

Postimees 1886a = Vanemuine. Postimees, No. 34, August 16, p. 4. Available at http:// dea.nlib.ee/JQ/fullview.php?frameset=3\&showset=1\&wholepage=suur\&pid=s94 2355\&nid=4222, last accessed on March 30, 2017.

Postimees 1886b = Suur rahvapidu. [A Big Folk Festival.] Postimees, No. 35, August 23, pp. 1-2. Available at http://dea.nlib.ee/JQ/fullview.php?frameset=3\&showset=1 $\&$ wholepage=suur\&pid=s289227\&nid=4223, last accessed on March 30, 2017.

Postimees 1889 = Sõnumid Tallinnast. [News from Tallinn.] Postimees, No. 91, August 12, p. 3. Available at http://dea.nlib.ee/JQ/fullview.php?frameset=3\&showset=1\&wh olepage $=$ suur\&pid=s681062\&nid=1291, last accessed on March 30, 2017.

Postimees 1895a = Wene-maalt. Kaugemalt riigist: Peterburist. [From Russia. From the Country's Faraway Corners: From St. Petersburg.] Postimees, No. 236, October 23, p. 2. Available at http://dea.nlib.ee/JQ/fullview.php?frameset=3\&showset=1\&wh olepage $=$ suur\&pid $=$ s444915\&nid $=581$, last accessed on March 30, 2017.

Postimees 1895b = Pime-põrgu poisid musta maa mehed. [Boys from Dark Hell, Men of the Black Country.] Postimees, No. 225, October 7, p. 4. Available at http://dea. nlib.ee/JQ/fullview.php?frameset=3\&showset=1\&wholepage=suur\&pid=s89050 7\&nid=552, last accessed on March 30, 2017.

Postimees 1895c = Kohalikud sõnumid. [Local News.] Postimees, No. 231, October 14, p. 3. Available at http://dea.nlib.ee/JQ/fullview.php?frameset=3\&showset=1\&w holepage $=$ suur\&pid=s655424\&nid=567, last accessed on March 30, 2017. 
Postimees 1897a = Kohalikud sõnumid. [Local News.] Postimees, No. 203, September 11, p. 3. Available at http://dea.nlib.ee/JQ/fullview.php?frameset=3\&showset=1\&wh olepage $=$ suur\&pid $=$ s655527\&nid $=1025$, last accessed on March 30, 2017.

Postimees 1897b = "Vanemuise" seltsi aias Jurjewis. [In the Garden of the Vanemuine Society in Yuryev.] Postimees, No. 176, August 11, p. 4. Available at http://dea. nlib.ee/JQ/fullview.php?frameset=3\&showset=1\&wholepage=suur\&pid=s 86846 $3 \&$ nid=886, last accessed on March 30, 2017.

Postimees 1899 = Kodumaalt: Tapalt. [From Homeland: From Tapa.] Postimees, No. 206, September 17, p. 3. Available at http://dea.nlib.ee/JQ/fullview.php?frameset=3\& showset=1\&wholepage=suur\&pid=s643288\&nid=3729, last accessed on March $30,2017$.

Postimees $1900=$ Kodumaalt: Äksist. [From Homeland: From Äksi.] Postimees, No. 182, August 16, p. 3. Available at http://dea.nlib.ee/JQ/fullview.php?frameset=3\&shows et=1\&wholepage=suur\&pid=s642781\&nid=5319, last accessed on March 30, 2017.

Prants, Hindrik 2016 [1910]. Petseri Eestlased. [Estonians from Pechory.] In: Hando Runnel (comp.) Eesti asi ja maailma lugu. Eesti mõttelugu 128. Tartu: Ilmamaa, pp. $28-34$.

Pulst, August 2014. Äratusmäng uinuvale rahvamuusikale. August Pulsti mälestusi. [An Awakening Tune for Latent Estonian Traditional Music: Memoirs of August Pulst.] Comp. by Krista Sildoja. Tallinn: Eesti Teatri- ja Muusikamuuseum.

Raun, Toivo U. 1981. The Estonians. In: Edward C. Thaden (ed.) Russification in the Baltic Provinces and Finland, 1855-1914. Princeton, NJ: Princeton University Press, pp. 287-356.

Reiman, Villem 1904. Setukeste laulud. [Songs of the Seto People.] Linda, Nos. 15 \& 16, pp. 290-294, 312-314. Available at http://dea.nlib.ee/fullview.php?frameset= $3 \&$ showset=1\&wholepage=keskmine\&pid=s1157321\&nid=133028\&con=0, http:// dea.nlib.ee/fullview.php?frameset=3\&showset=1\&wholepage=keskmine\&pid=s1 232463\&nid=133029\&con=0, last accessed on March 30, 2017.

Ritsing, Richard 1978. Räpina laulukoorid ja orkestrid. [Choirs and Ensembles of Räpina.] In: L. Jaanits (ed.) Põlva rajoonis: Kodu-uurijate seminarikokkutulek 17.-20. augustini 1978. Artiklite kogumik. Eesti NSV Teaduste Akadeemia, Koduuurimise Komisjon. Tallinn: Eesti NSV Teaduste Akadeemia, pp. 208-213.

Ritsing, Richard 1984. Muusikaelu. [On Musical Scene.] In: Valdek Ritslaid (comp.) Räpina radadel: Artikleid. Eesti NSV Teaduste Akadeemia, Kodu-uurimise Komisjon, Põlva Rajooni Täitevkomitee. Tallinn: Eesti NSV Teaduste Akadeemia, pp. 133-143.

Rohtla, Geiu 2005. Muusikaelu Tartus 19.-20. sajandi vahetusel ja Berliini Filharmoonikute kontserdid. [Tartu Music Life at the Turn of the 20th Century and Concerts of the Berlin Philharmonic Orchestra.] In: Urve Lippus (comp.) Muusikaelu Eestis 20. sajandi algupoolel. Eesti Muusikaloo Toimetised 7. Tallinn: Eesti Muusikaakadeemia, pp. 16-51.

Rohtla, Geiu 2006. Tartu Akadeemiline Musse ja muusikategemine 19. sajandi esimesel poolel (1814-1844). [Tartu Academic Musse and Music-Making in the First Half of the 19th Century (1814-1844).] Tuna: Ajalookultuuri ajakiri, No. 2, pp. 19-36. Available at http://www.digar.ee/arhiiv/et/perioodika/37100, last accessed on March 31, 2017. 
Sakala 1884 = Omalt maalt. [From Homeland.] Sakala, No. 24, June 16, p. 2. Available at http://dea.nlib.ee/JQ/fullview.php?frameset=3\&showset=1\&wholepage=suur\& pid=s489372\&nid=16239, last accessed on March 31, 2017.

Salve, Kristi 2000. Toone tare: Tähelepanekuid setu surnuitkude žanridevahelistest ja geograafilistest seostest. [Some Notes on Inter-Genre and Geographical Relations of Setu Laments.] In: Kristi Salve \& Mare Kõiva \& Ülo Tedre (eds.) Tagasipöördumatus: Sõnad ja hääl. Tartu: Eesti Kirjandusmuuseumi folkloristika osakond, pp. 55-72.

Schmalz, H. J. 1901. Alatarõ Hippo. Postimees, No. 250, November 3, p. 4. Available at http://dea.nlib.ee/JQ/fullview.php?frameset=3\&showset=1\&wholepage=suur\&p $\mathrm{id}=\mathrm{s} 897669 \&$ nid=3453, last accessed on March 31, 2017.

Schmalz, Hermann Julius 2013. Töganitsa Höödo, Alatarõ Hipo ja tõsõ’: Hermann Julius Schmalzi juttõ. [Höödo from Töganitsa Village, Hipo of Alatarõ, and Others: Stories by Hermann Julius Schmalz.] Comp. by Kristiina Tiideberg. Seto kirävara 5. Värska: Seto Instituut.

Tallinna Sõber 1889 = Omalt maalt. [From Homeland.] Tallinna Sõber, No. 34, August 18, p. 3. Available at http://dea.nlib.ee/JQ/fullview.php?frameset=3\&showset=1\&who lepage=suur\&pid=s704722\&nid=70155\&con=0, last accessed on March 31, 2017.

Tampere, Herbert 1956. Mõningaid eestlaste etnilise ajaloo küsimusi suulise rahvaloomingu valgusel. [Some questions of Estonian ethnogenesis in the light of oral literature.] In: Harri Moora (ed.) Eesti rahva etnilisest ajaloost. Tallinn: Eesti Riiklik Kirjastus, pp. 255-277.

Tampere, Herbert 1965. Eesti rahvalaule viisidega 5. [Estonian Folk Songs with Melodies.] Tartu: Eesti NSV Teaduste Akadeemia Fr. R. Kreutzwaldi nim. Kirjandusmuuseum.

Tenhunen, Anna-Liisa 2006. Itkuvirren kolme elämää: Itkuvirsien käytön muuttuminen. [The Three Lives ofLament: Transformations in Lament Behavior.] Suomalaisen Kirjallisuuden Seuran Toimituksia 1051. Helsinki: Suomalaisen Kirjallisuuden Seura.

Toomeos-Orglaan, Kärri 2015. Mida setod lugesid? “Kirjaoskamatud” setod kirjakultuuri mõjuväljas. [What Did Seto People Read? The Influence of Literary Culture on "Illiterate" Setos.] Keel ja Kirjandus, Nos. 8-9, pp. 603-622. Available at http:// kjk.eki.ee/ee/issues/2015/8-9/685, last accessed on March 31, 2017.

Upton, Janet L. 2002. The Politics and Poetics of Sister Drum: "Tibetan" Music in the Global Marketplace. In: Timothy J. Craig \& Richard King (eds.) Global Goes Local: Popular Culture in Asia. Vancouver \& Toronto: University of British Columbia Press, pp. 99-119.

Uus Aeg 1899 = Kirjasaatjatelt: Räpinast. [From Our Correspondents: From Räpina.] Uus Aeg, No. 35, August 27, p. 3. Available at http://dea.nlib.ee/JQ/fullview. php?frameset=3\&showset=1\&wholepage $=$ suur\&pid=s707006\&nid=30765, last accessed on March 29, 2017.

Vahtra, Jaan 1935. Minu noorusmaalt. II. Autobiograafilisi pilte ja jutustusi aastailt 1899-1909. [The Land of My Youth. II: Autobiographical Pictures and Stories from 1899 to 1909.] Tartu: Noor-Eesti.

Valkonen, Sanna 2009. Poliittinen saamelaisuus. [Political Saminess.] Tampere: Vastapaino. 
Võrumaa 1926 = Võrumaa: Maadeteaduslik, tulunduslik ja ajalooline kirjeldus. [Võrumaa: A Geographic, Economic, and Historical Description.] Edited by Jaan Rumma \& August Tammekann \& Johannes Voldemar Veski. Tartu: Eesti Kirjanduse Selts. Available at http://www.digar.ee/arhiiv/et/books/62924, last accessed on March 31, 2017.

Andreas Kalkun works as researcher at the Estonian Folklore Archives of the Estonian Literary Museum, Estonia, and has a PhD in folkloristics from the University of Tartu. andreas@folklore.ee 